\title{
$1 \quad$ Staphylococcus aureus nt5 gene contributes to bacterial infection ability to form kidney abscess
}

4 Yang Ye,, ${ }^{\#, a}$ Xinpeng Liu, ${ }^{\#, a}$ Zijing Xia, ${ }^{b}$ Min Tang, ${ }^{a}$ Dan Zhang, ${ }^{a}$ Fuqiang He, ${ }^{a}$ Peng

5 Zhang, ${ }^{\mathrm{c}}$ Shufang Liang,

6

$8{ }^{\mathrm{a}}$ State Key Laboratory of Biotherapy and Cancer Center, West China Hospital, Sichuan

9 University, and Collaborative Innovation Center for Biotherapy, No.17, 3rd Section of

10 People's South Road, Chengdu, 610041, P. R. China.

$11{ }^{\mathrm{b}}$ Department of Rheumatology, West China Hospital, Sichuan University, Chengdu,

12 610041, Sichuan, P. R. China.

$13{ }^{\mathrm{c}}$ Department of Urinary Surgery, West China Hospital, Sichuan University, Chengdu,

14 610041, Sichuan, P. R. China.

15

$16 \quad$ Equal contribution to the work.

$17 *$ Correspondence to: Dr. Shufang Liang, State Key Laboratory of Biotherapy and Cancer

18 Center, West China Hospital, Sichuan University, No.17, 3rd Section of People's South

19 Road, Chengdu, 610041, P. R. China. E-mail: zizi2006@ scu.edu.cn. 


\section{Abstract}

Staphylococcus aureus (S. aureus) is a commonly conditional infection pathogen, in which several key virulence genes are responsible for bacterial infection ability. The $S$. aureus nt5 gene, encoding 5'-nucleotidase, mediates bacterial nucleic acid pathway, yet it is nearly unknown of $n t 5$ function for staphylococcal infection ability. Herein we have constructed $S$. aureus mutant with the gene $n t 5^{\mathrm{C} 166 \mathrm{~T}}$ silence $(S$. aureus $\Delta n t 5$ ) by a CRISPR RNA-guided base editing system to investigate bacterial infection ability in vitro and in vivo. As expected, several $n t 5$-related genes are disturbed in $S$. aureus $\Delta n t 5$, in which gene transcription level of py is decreased compared with the wild-type $S$. aureus. Bacterial gene $n t 5$ is downregulated and py/adk are upregulated when $S$. aureus is exposed to antibiotics daptomycin, which indicates $n t 5$-mediated nucleic acid pathway is interfered upon with daptomycin treatment. Furthermore, the mutant $\Delta n t 5$ displays about a 40 -fold reduction of bacterial loading in mouse kidney on a mouse sepsis model, and the infection ability of $\Delta n t 5$ is reduced than the wild-type bacteria. The gene $n t 5$ contributes to $S$. aureus-infected abscess formation in mouse kidney, and the silence of $n t 5$ gene promotes phagocytosis of $S$. aureus by mouse and human immunocytes. In general, our findings reveal $n t 5$ silence impedes bacterial loading in kidney to form abscess but enhances $S$. aureus to be phagocytosed by host cell immune system in vitro and in vivo, which indicates that $n t 5$ gene plays an important role in bacterial infection and immune evasion. 
bioRxiv preprint doi: https://doi.org/10.1101/2022.02.09.479838; this version posted February 10, 2022. The copyright holder for this preprint (which was not certified by peer review) is the author/funder. All rights reserved. No reuse allowed without permission.

43 Keywords: Staphylococcus aureus, nt5 gene, 5'-nucleotidase, gene silence,

44 abscess, phagocytosis, daptomycin

45

46

47

48

49

50

51

52

53

54

55

56

57

58

59

60

61

62

63

64

\section{Introduction}

Staphylococcus aureus (S. aureus) is a commonly conditional pathogen causing severe infections in almost every organ of human body, including sepsis, endocarditis, skin and wound infections, or osteomyelitis (1). Treatment of $S$. aureus-induced infections has become increasingly challenging due to emergence of drug-resistant bacteria (2). Drug resistance to many clinically used antibiotics becomes more and more serious, even several powerful antibacterial antibiotics, such as (DAP), vancomycin and linezolid, have suffered from antibiotics resistance $(3,4)$. Emergence of drug resistance always overspeeds the development of new antibiotics. Hence, it is necessary to explore key pathogenicity-driven genes and their infection mechanism of $S$. aureus, which contributes to develop novel therapeutic means against $S$. aureus infections.

DAP is a novel cyclic lipopeptide antibiotic, which interacts with bacterial cell membrane to efficiently kill most clinically relevant Gram-positive bacteria (5). Our previous research has identified several key DAP-targeting bacterial proteins through quantitative drug proteomic analysis on the conditional pathogenic bacteria $S$. aureus (6). The downregulation of $n t 5$ (gi 446956624) upon DAP exposure leads to decrease of bacterial membrane potential and disruption of cell membrane, which contributes to bacterial DNA rapid release and finally causes bacteria death (6). Both 
bioRxiv preprint doi: https://doi.org/10.1101/2022.02.09.479838; this version posted February 10, 2022. The copyright holder for this preprint (which was not certified by peer review) is the author/funder. All rights reserved. No reuse allowed without permission.

65

66

67 genes py (gi 487015361) and $a d k$ (gi 488431505) are essential in $n t 5$-mediated adenine metabolism of $S$. aureus (7). DAP disrupts kinase activity of py-encoding pyruvate kinase (PY, protein ID: ODV52833.1) and ADK (protein ID: WP_002500890.1) to mediate adenine metabolism pathway (6). These evidences indicate bacterial $n t 5$ gene and bacterial adenine synthesis are tightly related with DAP antibacterial effect.

The $n t 5$-encoding 5'-nucleotidase (NT5, protein ID: ABD29455.1) protein is ubiquitous among bacteria species, including E coli, S. aureus and Streptococcus suis (8), which hydrolyzes the phosphate group of 5'-nucleotide. Most of the soluble intracellular NT5 from bacteria belongs to the vast haloacid dehalogenase superfamily, such as E. coli NagD (9) and S. aureus NT5. In Bacillus subtilis, YcsE and YktC as major NT5s both exhibit 5'-nucleotide phosphatase activity (10). Streptococcus suis NT5 is an important virulence factor enabling to inhibit neutrophil functions in vitro by converting adenosine monophosphate to adenosine (Ado) (8). More noticeably, bacterial NT5 activity is associated with immune evasion properties (11). But it is nearly unclear how does $S$. aureus NT5 function in S. aureus-induced infection before.

2 During infection, Staphylococcal nuclease and adenosine synthase A (adsA, protein ID: ALY19673.1) converts neutrophil extracellular traps to deoxyadenosine (dAdo), which is toxic to human immune cells and kills phagocytes and macrophages (12). The Ado and dAdo suppress immune responses and have immunoregulatory attributions $(13,14)$. In $S$. aureus, adsA encoded by gene ads A (gi 
87 59698588) is a cell wall-anchored enzyme to convert AMP/dAMP to Ado/dAdo,

contributing to $S$. aureus escaping from phagocytic clearance and formation of organ abscesses in vivo (15). The adsA harbors NT5 signature sequence which is critical for catalytic activity of mammalian enzymes (16). NT5 activity of $S$. aureus is a mediator of virulence attributes of adsA (15). Although NT5s are widespread among all domains of life, it is unclear whether $S$. aureu NT5 with a $33.3 \mathrm{kD}$-molecular weight has similar properties as adsA.

To assess the role of NT5 activity toward DAP treatment and Staphylococcal infection ability, herein we focus on gene function of $S$. aureus $n t 5$ and its effects on bacterial infection ability. Using lose-of-functional mutant strain with $n t 5^{\mathrm{C} 166 \mathrm{~T}}$ gene silence performed by a CRISPR RNA-guided base editing system, we have revealed S. aureus $n t 5$ gene is required for $S$. aureus-induced abscess formation. Moreover, we have confirmed the antibiotics DAP exposure to $S$. aureus leads to downregulation of genes $n t 5$ and $a d s A$, and upregulation of genes py and $a d k$, therefore $n t 5$-mediated bacterial nucleic acid metabolic pathway is disturbed by DAP. We also have revealed the silence of $n t 5$ gene promotes the killing of $S$. aureus by immune cells. Our findings indicate disruption of the $n t 5$-invovling bacterial activities provides a potentially novel therapeutic means against $S$. aureus even the emerging antibiotic-resistant pathogens.

\section{Materials and methods}

\section{Reagents and chemicals}


111 plasmid screening in E. coli and plasmid curing in S. aureus RN4220 and S. aureus

SsoAdvanced SYBR GreenSupermix were bought from Bio-Rad for qRT-PCR.

Beijing Dakewei Company. MojoSort human CD14+ monocytes isolation kit was purchased from Hyclone.

\section{Strains and plasmids}

121 The bacterial strains including S. aureus ATCC 25923 and S. aureus RN4220 were on tryptic soy broth (TSB), then was inoculated into $5 \mathrm{~mL}$ TSB to grow overnight at 
131 plasmid selection in S. aureus. The repF is a temperature-sensitive origin for plasmid

curing in S. aureus.

\section{Plasmid construction of pnCasSA-BEC-NT5sp}

We designed a $20 \mathrm{bp}$-spacer oligo to insert in $B s a \mathrm{I}$ site of the pnCasSA-BEC plasmid by Golden Gate assembly. The plasmid from the Golden Gate assembly reaction was transformed into $100 \mu \mathrm{L}$ competent $E$. coli $\mathrm{DH} 5 \alpha$ cells to incubate at $37^{\circ} \mathrm{C}$ overnight, and the recombinant plasmid pnCasSA-BEC-NT5sp was sequenced for verifying correctness of plasmid construction.

\section{S. aureus competent cells}

The electrocompetent cells of S. aureus strains were prepared as following procedures. A single colony of each $S$. aureus strain was inoculated into $2 \mathrm{~mL}$ TSB to incubate at $30^{\circ} \mathrm{C}$ for $12 \mathrm{~h}$. Cells were diluted with a ratio of $1: 100$ into $100 \mathrm{~mL}$ fresh TSB medium, then were cultured up to $\mathrm{OD}_{600}$ value with $0.3-0.4$ and chilled on ice for $20 \mathrm{~min}$. Cells were harvested by centrifugation with $5000 \mathrm{rpm}$ at $4{ }^{\circ} \mathrm{C}$ for 5 min, and washed twice with $0.5 \mathrm{M}$ sterile ice-cold sucrose. Cells were suspended into $1 \mathrm{~mL} 0.5 \mathrm{M}$ sucrose, from which $100 \mathrm{uL}$ aliquots were frozen in liquid nitrogen and stored at $-80^{\circ} \mathrm{C}[18]$.

\section{Modified plasmid transformation by electroporation}

The pnCasSA-BEC-NT5sp plasmid was transformed into the competent cells of 
bioRxiv preprint doi: https://doi.org/10.1101/2022.02.09.479838; this version posted February 10, 2022. The copyright holder for this preprint (which was not certified by peer review) is the author/funder. All rights reserved. No reuse allowed without permission.

153 laboratory strain $S$. aureus RN4220 by electroporation to get the modified plasmid.

154 Before cell electroporation, $100 \mathrm{uL}$ competent cells and the plasmid

155 pnCasSA-BEC-NT5sp were respectively thawed on ice for $5 \mathrm{~min}$. The cells were

156 mixed with $1 \mathrm{ug}$ of the recombinant plasmid, and transferred into an electroporation

157 cuvette with $1 \mathrm{~mm}$-thickness at room temperature. After being pulsed at $2.1 \mathrm{kV} \mathrm{mm}$,

$158100 \mathrm{U}$ and $25 \mathrm{mF}$, cells were immediately supplied with $900 \mu \mathrm{L}$ TSB and recovered at

$15930^{\circ} \mathrm{C}$ for $1.5 \mathrm{~h}$. Finally, $500 \mu \mathrm{L}$ cells were plated onto a TSB plate containing $5 \mathrm{mg} / \mathrm{L}$

160 chloramphenicol for incubation at $30^{\circ} \mathrm{C}$ for $24 \mathrm{~h}(18)$. The genomic DNAs of the

161 target colonies were extracted to confirm base mutation in the target site by 162 sequencing.

163

\section{Base editing in S. aureus 25923}

165 To acquire $n t 5^{\mathrm{C} 166 \mathrm{~T}}$ gene silence $(\Delta n t 5)$ in the conditionally infectious pathogen $S$. aureus ATCC 25923 (S. aureus $\Delta n t 5)$, the assembled plasmid isolated from $S$. aureus RN4220 was transformed into S. aureus ATCC 25923 by electroporation

168 performed as above. $1 \mathrm{~mL}$ cells were plated onto a TSB plate containing $5 \mathrm{mg} / \mathrm{L}$ 169 chloramphenicol to incubate at $30{ }^{\circ} \mathrm{C}$ for $24 \mathrm{~h}$. The target colonies were screened to 170 extract genomic DNAs for sequencing to confirm $n t 5^{\mathrm{C} 166 \mathrm{~T}}$ in S. aureus ATCC 25923. 171 The method of plasmid curing was referenced Ji's article (18).

174 We selected a 20 bp-spacer sequence before a PAM site (NGG) in the target gene 
bioRxiv preprint doi: https://doi.org/10.1101/2022.02.09.479838; this version posted February 10, 2022. The copyright holder for this preprint (which was not certified by peer review) is the author/funder. All rights reserved. No reuse allowed without permission.

175 locus for designing sgRNAs. Two oligos were designed as qRT-PCR primers (Table 1). The total RNA was isolated using bacterial RNA extraction kit following the

177 manufacturer's protocol (RE-03111, FOREGENE Company). The expression levels

178 of genes $n t 5$ and $p y$, $a d k$ were normalized to that of the reference Tpi gene. Each 179 gene expression was quantified by qPCR for three times $(\mathrm{n}=3)$.

180

181

\section{Minimal inhibitory concentration (MIC) of DAP}

The MIC of DAP on S. aureus 25923/ $\Delta n t 5$ was determined by broth microdilution following the Clinical Laboratory Standards Institute guidelines. DAP was serially diluted to final concentrations ranged from 0.03125 to $16 \mu \mathrm{g} / \mathrm{mL}$. The MIC was measured by three experiment repeats.

\section{Mouse sepsis model}

The following experiments on BALB/c mice, including a mouse sepsis model, immune evasion and phagocytosis, were approved by the Animal Care Committee of Sichuan University (Chengdu, China). The infection ability of $S$. aureus ATCC 25923 (WT) and $\Delta n t 5$ was respectively assayed on a mouse sepsis model. Overnight cultures of each $S$. aureus, including the WT and $\Delta n t 5$, were diluted 1:100 into fresh TSB and grown for $3 \mathrm{~h}$ at $37^{\circ} \mathrm{C}$. Then each staphylococci culture was centrifuged, washed twice, and diluted in PBS to yield an $\mathrm{OD}_{600}$ up to 0.5 with $10^{8}$ colony-forming units $(\mathrm{CFU}) / \mathrm{mL} .10^{6} \mathrm{CFU}$ bacterial suspension was administered via tail intravenous into a 6-week-old male $\mathrm{BALB} / \mathrm{c}$ mouse. Totally ten mice were 
197 inoculated with each strain culture, however, two mice died of S. aureus WT

198 infection during experiment progression.

199 On the $5^{\text {th }}$ day of bacteria inoculation, mice were killed to observe the abscess

200 formation in kidneys and staphylococcal survival in kidneys and livers. Mouse's left

201 kidney and left lobe liver were respectively collected to homogenize with PBS

202 containing $1 \%$ Triton X-100. Aliquots of homogenates were diluted and plated on

203 TSB agar plates for triplicate measurements of CFUs. Histopathology analysis of

204 mouse right kidney tissue was performed as following. Tissues were incubated at

205 room temperature in $10 \%$ formalin for $24 \mathrm{~h}$, and embedded in paraffin to be

206 sectioned, stained with hematoxylin-eosin to examine by microscopy. Data were

207 obtained from each representative group samples with cohorts of six mice.

208

209 Cell culture

210 The murine macrophage RAW 264.7 cells and human myeloid leukemia

211 mononuclear THP-1 cells were respectively cultured in Dulbecco's Modified

212 EagleMedium (DMEM, Hyclone) and Roswell Park Memorial Institute (RPMI 1640,

213 Hyclone) media supplemented with $10 \%$ fetal bovine serum (FBS) at $37{ }^{\circ} \mathrm{C}$ and $5 \%$

$214 \mathrm{CO}_{2}$. Cells were cultured for $48 \mathrm{~h}$, and collected to adjust cell density to $10^{7}$ cells $/ \mathrm{mL}$

215 for assay.

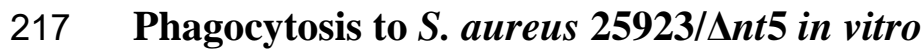

$218 S$. aureus $25923 \mathrm{WT}$ and mutant $\Delta n t 5$ were cultured overnight, from which $1 \mathrm{~mL}$ 
219 bacteria was cultured with $100 \mathrm{~mL}$ TSB medium for additional $3 \mathrm{~h}$ at $37^{\circ} \mathrm{C}$ to detect

220 their phagocytosis by monocytes. As mentioned above, each staphylococci culture

221 was centrifuged, washed twice, and diluted in PBS to yield an OD600 up to 0.5 with

$22210^{8}$ colony-forming units (CFU) $/ \mathrm{mL} .10^{6} \mathrm{CFU}$ bacterial suspension was mixed with $2235 \times 10^{5}$ RAW264.7 or THP-1, and cultured at $37^{\circ} \mathrm{C}$ from 15 to 90 min respectively to 224 plate on TSA and count on the next day.

225 The following experiments were approved by the West China Hospital Medical 226 Center Institutional Review Board of Sichuan University, following the guidelines of 227 the West China Hospital Medical Center Institutional Review Board of Sichuan 228 University. The enrolled volunteers provided written consent to participate in this 229 study. To further measure $S$. aureus $25923 / \Delta n t 5$ survival ability under the existence 230 of ex vivo neutrophils, $1 \mathrm{~mL}$ peripheral blood was respectively collected from 8 $231 \mathrm{BALB} / \mathrm{c}$ mice and $5 \mathrm{~mL}$ peripheral blood was collected from 3 human volunteers. $2322.5 \times 10^{4} \mathrm{CFU}$ bacteria was mixed with $225 \mu \mathrm{L}$ of mouse blood, and $10^{6} \mathrm{CFU}$ bacteria 233 was mixed with $900 \mu \mathrm{L}$ of human blood to incubate at $37^{\circ} \mathrm{C}$ with slow rotation [15].

234 The mixture of bacteria with mouse or human blood were sampled after incubation 235 for 30 and 90 minutes, from which aliquots were incubated with $0.5 \%$ saponin/PBS 236 on ice for $30 \mathrm{~min}$. Dilutions of staphylococci were plated on TSA for enumeration of 237 surviving CFUs. 
bioRxiv preprint doi: https://doi.org/10.1101/2022.02.09.479838; this version posted February 10, 2022. The copyright holder for this preprint (which was not certified by peer review) is the author/funder. All rights reserved. No reuse allowed without permission.

240 The remaining $4 \mathrm{ml}$ peripheral blood samples were collected from each donor and

241 diluted with isotonic PBS to isolate lymphocyte using separation solution

242 (DKW-LSH-0100, Beijing Dakewei Company). After centrifugation with 250g for

$24310 \mathrm{~min}$, cells in the plasma layer were collected to isolate CD14 ${ }^{+}$monocytes using a

244 commercial kit (MojoSort human CD14+ monocytes isolation kit, 480047, Biolegend)

245 according to the manufacturer's protocol. Generally, the cells were resuspended with

246 MojoSort ${ }^{\mathrm{TM}}$ buffer to adjust to $10^{8}$ cells, from which $100 \mathrm{uL}$ suspension was taken

247 into a new centrifuge tube to mix with $10 \mathrm{uL}$ Biotin-antibody cocktail and $5 \mathrm{uL}$

248 Human TruStain FcX $\mathrm{FM}^{\mathrm{TM}}$ to incubate at room temperature for $10 \mathrm{~min}$. Then $10 \mathrm{uL}$

249 Streptavidin nanobeads were mixed to incubate on ice for $15 \mathrm{~min}$, and cells were

250 cleaned and collected by centrifugation at $300 \mathrm{~g}$ for $5 \mathrm{~min}$, then $2.5 \mathrm{~mL}$ of

251 Mojosort $^{\mathrm{TM}}$ was added to collect the decanted liquid on a centrifuge tube via a 252 magnet device. Finally, $5 \times 10^{5}$ cells were mixed with $10^{6} \mathrm{CFU}$ bacteria, cultured at $25337^{\circ} \mathrm{C}$, sampled at 30,60 and 90 min respectively, plated and counted the survival rate 254 of bacteria.

256 Immune evasion ability of $S$. aureus 25923 / $\Delta n t 5$ detected on mouse

257 In order to detect the immune evasion ability of $S$. aureus $25923 / \Delta n t 5$ in vivo, we 258 injected $10^{6} \mathrm{CFU}$ bacteria of $S$. aureus $25923 / \Delta n t 5$ from the tail vein for $5 \mathrm{BALB} / \mathrm{c}$ 259 mice, and collected $100 \mu \mathrm{L}$ blood from mouse orbit after infection for 30, $90 \mathrm{~min}$. 260 Aliquots were incubated with $0.5 \%$ saponin/PBS on ice for $30 \mathrm{~min}$ to lyse host 
bioRxiv preprint doi: https://doi.org/10.1101/2022.02.09.479838; this version posted February 10, 2022. The copyright holder for this preprint (which was not certified by peer review) is the author/funder. All rights reserved. No reuse allowed without permission.

261 eukaryotic cells. Dilutions were plated on TSA plates for enumeration of surviving

CFUs.

\section{Hemolysis assay in vitro}

S. aureus WT and $\Delta n t 5$ were grown in TSB at $37^{\circ} \mathrm{C}$ overnight and diluted in TSB

to yield an OD600 up to 0.5 with $10^{8}$. Then $1 \mu \mathrm{L}$ of culture of each strain including $S$. aureus 25923 and $\Delta n t 5$ was loaded onto a sheep blood plate [17] to incubate at $37{ }^{\circ} \mathrm{C}$ for $24 \mathrm{~h}$ for observing their hemolytic circle size.

\section{Results}

\section{Construction of $n t 5^{\mathrm{C} 166 \mathrm{~T}}$ mutant by a CRISPR RNA-guided editing system}

To investigate the loss-of-function of $n t 5$ gene, we constructed gene silence

277 uridine (U) through a deamination reaction. This base editor has an editable window

278 from positions 4 to 8 in the spacer sequence and it can achieve $\mathrm{C} / \mathrm{T}$ conversion 279 without homologous recombination (Fig. 1A), which is efficient for gene 280 inactivation in $S$. aureus.

281 We constructed the pnCasSA-BEC-NT5sp plasmid by Golden Gate assembly, then each of $200 \mathrm{ng} / \mu \mathrm{L}$ plasmids was transformed into the laboratory strain S. aureus 
bioRxiv preprint doi: https://doi.org/10.1101/2022.02.09.479838; this version posted February 10, 2022. The copyright holder for this preprint (which was not certified by peer review) is the author/funder. All rights reserved. No reuse allowed without permission.

283 RN4220 with $100 \%$ efficiency by electroporation. The base C166 of $n t 5$ gene in $S$.

284 aureus $\mathrm{RN} 4220$ was mutated to $\mathrm{T}\left(n+5^{\mathrm{C} 166 \mathrm{~T}}\right)$, which led to produce a premature stop

285 codon with TAA (Fig. 1B). Correspondingly, the mutant $n t 5$-encoding protein

286 5'-nucleotidase (mNT5) was a truncated mutant in which the natural amino acid Q56

287 of the wild-type NT5 was mutated and terminated due to emergence of the premature 288 stop codon TAA.

289 S. aureus RN4220 retains the methylation function of the Sau I system, which thus 290 appropriately methylates DNA for subsequent uptake by other target S. aureus 291 strains containing restriction-modification systems. Firstly, we transferred the 292 recombinant plasmids pnCasSA-BEC-NT5sp modified by S. aureus RN4220 to our 293 target object $S$. aureus ATCC 25923, in which the pnCasSA-BEC-NT5sp system 294 enabled highly efficient $\mathrm{C} / \mathrm{T}$ conversion for target base editing. The $\mathrm{C}$ at position 7 295 of spacer in $n t 5$ gene was mutated to $\mathrm{T}$ with $100 \%$ efficiency (Fig. 1C), which 296 indicated that C166 of $n t 5$ gene of the $S$. aureus ATCC 25923 strain was mutated to 297 T so that Q56 amino acid of the wild-type NT5 protein was interrupted and 298 terminated at translational level due to emergence of the mutant premature stop 299 codon TAA.

300 Although the gene nt5 was not deleted, the endogenous encoding wild-type 301 protein NT5 was interrupted to lose their normal functions. After plasmid curing, 302 four randomly picked colonies grew normally in the absence of chloramphenicol 303 whereas none of them could grow in the presence of the antibiotic after two passages 304 (Fig. 1D). Meanwhile, no assembled plasmid was detectable in S. aureus $\Delta n t 5$ (Fig. 
bioRxiv preprint doi: https://doi.org/10.1101/2022.02.09.479838; this version posted February 10, 2022. The copyright holder for this preprint (which was not certified by peer review) is the author/funder. All rights reserved. No reuse allowed without permission.

305 1E), which confirmed a stable removal of the pnCasSA-BEC-NT5sp plasmid from 306 the host strain S. aureus ATCC 25923. All base mutations were verified by 307 sequencing.
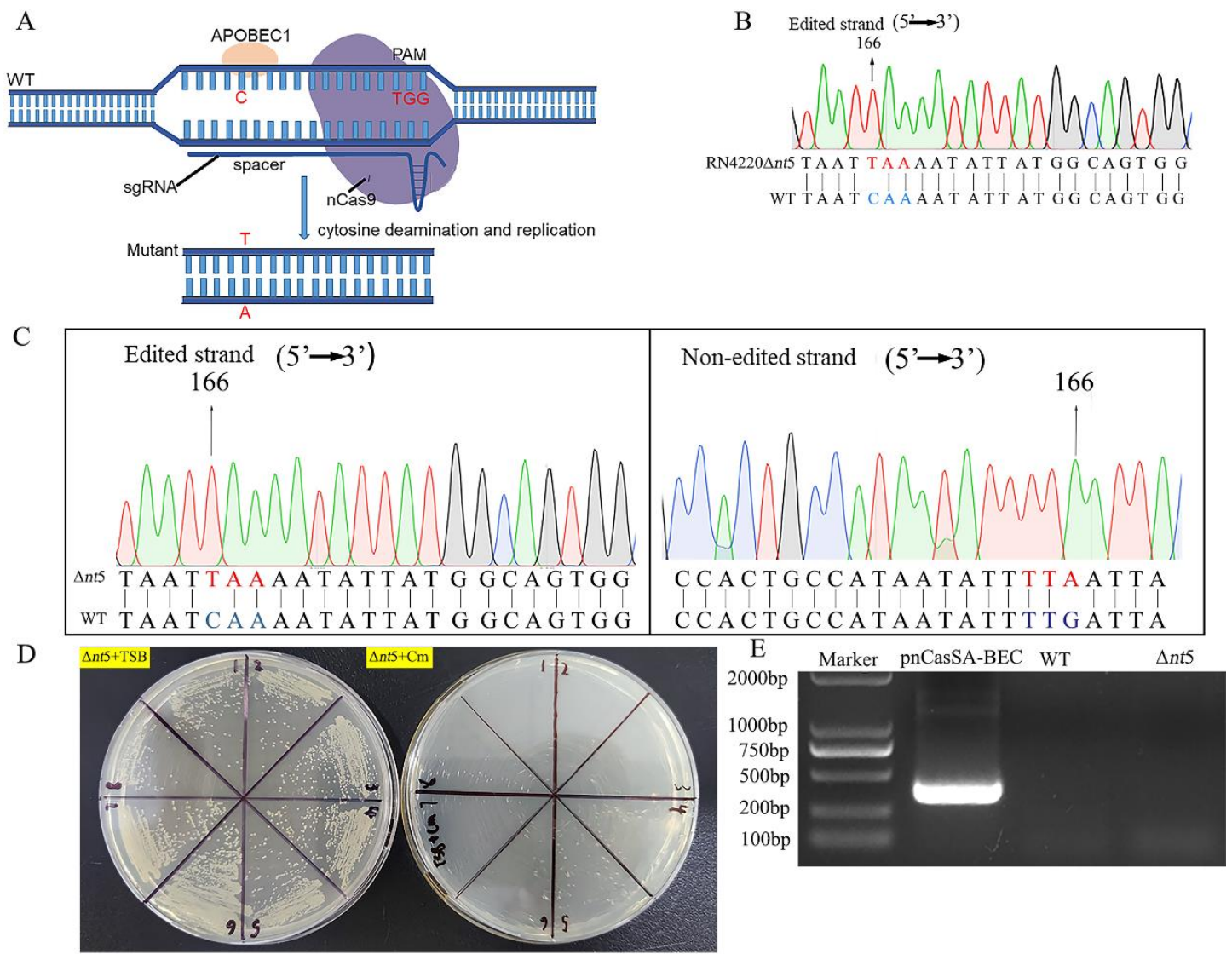

308

Fig. 1. Construction of $n t 5^{\mathrm{C} 166 \mathrm{~T}}$ gene silence $S$. aureus $\Delta n t 5$. (A) Composition of the base editor pnCasSA-BEC system. It mainly includes APOBEC1-nCas9, cap1A and rpsL promoters, and it can be directed to any genomic locus by the Cas $9 / \mathrm{sgRNA}$ complex to achieve $\mathrm{C} / \mathrm{T}$ conversion in positions 4 to 8 of the spacer sequence without homologous recombination. PAM: protospacer adjacent motif. (B-C) The C166 of $n t 5$ gene was mutated to $\mathrm{T}$ in the edited nucleotide strand in the $S$. aureus RN4220 (B) and S. aureus 25923 (C) respectively. (D-E) The pnCasSA-BEC-NT5sp plasmid was easily cured from $S$. aureus $\Delta n t 5$ after base editing. The individual colonies obtained after the curing steps were streaked onto the TSB agar plates in the 
318 presence (D, right) or absence (D, left) of $\mathrm{Cm}$ to test the effectiveness of curing (D),

319 and (E) the PCR result showed that the assembled plasmids disappeared in $\Delta n t 5 . \mathrm{Cm}$ :

320 chloramphenicol, WT: wild type.

\section{The $n t 5$ mutation leads to expression decrease of gene $p y$ and $a d k$}

The gene $a d k$, and $p y$ are essential in $n t 5$-mediated nucleic acid metabolism of $S$.

aureus based on the reported literature and bioinformatics analysis by STRING

software (http://string-db.org/cgi/input.pl) (19). We further verified if $n t 5$ gene

mutation had influences on the two gene transcription levels. Therefore, the gene

transcription levels of $n t 5$, adk and py were detected on mutant $\Delta n t 5$ to learn about

their gene level changes along with the single base mutation of gene $n t 5$.

As results, compared with WT, the RNA levels of $n t 5$ and py in S. aureus $\Delta n t 5$

(Fig. 2A and 2B). Gene transcriptional level of $a d k$ was 1.55-times of

332 downregulation, which indicated the silencing of $n t 5$ gene led to the destruction of

333 this nucleic acid pathway $(\mathrm{p}<0.01)$ (Fig. 2C). However, the growth rate of mutant $S$.

334 aureus $\Delta n t 5$ was similar with the wild-type S. aureus (S. aureus WT) (Fig. 2D),

335 which indicated $n t 5$ gene had little direct influence on the growth rate of $S$. aureus 

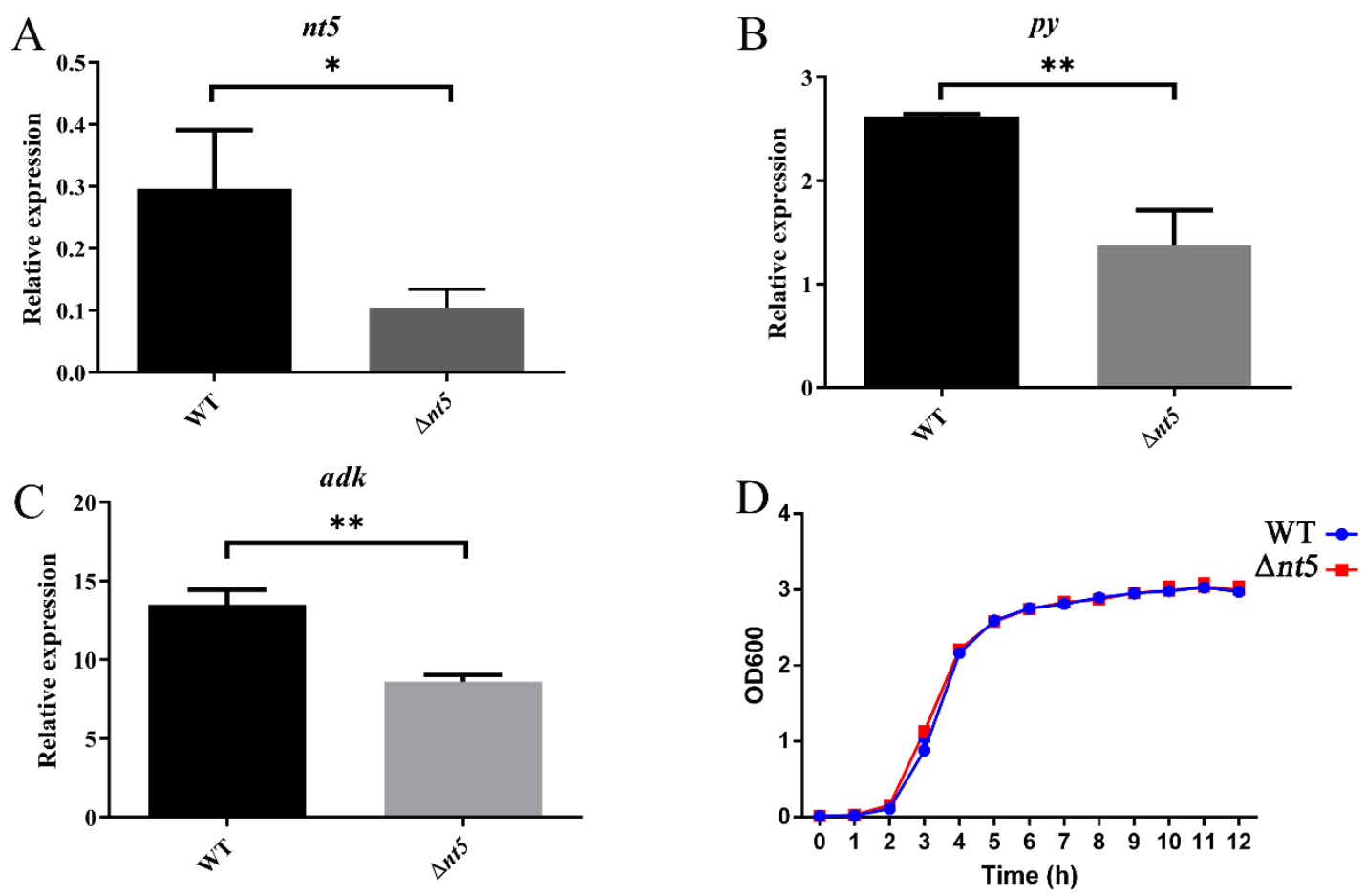

Fig. 2. The mRNA expression level of target gene in gene silence mutant $\Delta n t 5$.

339 (A) The $n t 5$ gene expression in $\Delta n t 5$ mutant was deceased in comparison with WT.

340 (B) The mRNA level of py gene was downregulated in $\Delta n t 5$ compared with WT. (C)

341 Compared with WT, lower $a d k$ mRNA was detectable in $\Delta n t 5$. (D) The mutant strain

$342 \Delta n t 5$ exhibited a similar growth rate to the WT. WT: wild type, py: pyruvate kinase,

343 adk: adenylate kinase, $* \mathrm{P}<0.5, * * \mathrm{p}<0.01$.

$n t 5^{\mathrm{C} 166 \mathrm{~T}}$ mutant phenotype and relative gene expression changes in response to

\section{DAP exposure}

347 We further studied the phenotype changes of the $n t 5^{\mathrm{C} 166 \mathrm{~T}}$ mutant $\Delta n t 5$ upon DAP

348 treatment. The MIC values of DAP on $\Delta n t 5$ mutant was proximately $0.5 \mathrm{mg} / \mathrm{L}$,

349 which had little significant differences from the WT upon DAP treatment. Upon 0.5

350 MIC $(0.25 \mathrm{mg} / \mathrm{L})$ DAP treatment, the mRNA level of $n t 5$ was downregulated by 2.90 
351 times in S. aureus WT, while there was no significant change of $n t 5^{\mathrm{C} 166 \mathrm{~T}}$ in $S$. aureus

$352 \Delta n t 5$ when compared to without DAP-exposed bacteria $(\mathrm{p}<0.05)$ (Fig. 3A). The

353 results indicate $S$. aureus $n t 5$ gene is key and sensitive to antibiotics DAP exposure,

354 which has been confirmed in our previous studies [6]. The mRNA level of py was

355 1.96-times upregulation in WT upon $0.25 \mathrm{mg} / \mathrm{L}$ DAP exposure, but py had no 356 significant change in $\Delta n t 5$ with DAP treatment $(\mathrm{p}<0.05)$ (Fig. 3B). In addition, the 357 mRNA level of $a d k$ gene was upregulated respectively by 2.06 and 2.35 times in WT 358 and $\Delta n t 5$ upon DAP exposure (p<0.001, $\mathrm{p}<0.0001)$ (Fig. 3C).

359 Above all, it showed that mutation of the key pathogenic gene $n t 5$ would induce 360 gene transcription changes of $n t 5$-related genes $p y$ and $a d k$ upon DAP exposure.

361 Although that the silence of $n t 5$ gene leads to the destruction of nucleic acid pathway,

362 but the silence of $n t 5$ gene has no direct influence on growth of bacteria. So far, we 363 speculate that the silence of $n t 5$ gene may affect the virulence of bacteria, and we 364 further investigate $n t 5$ roles for $S$. aureus pathogenesis, specially focusing on abscess 365 formation.
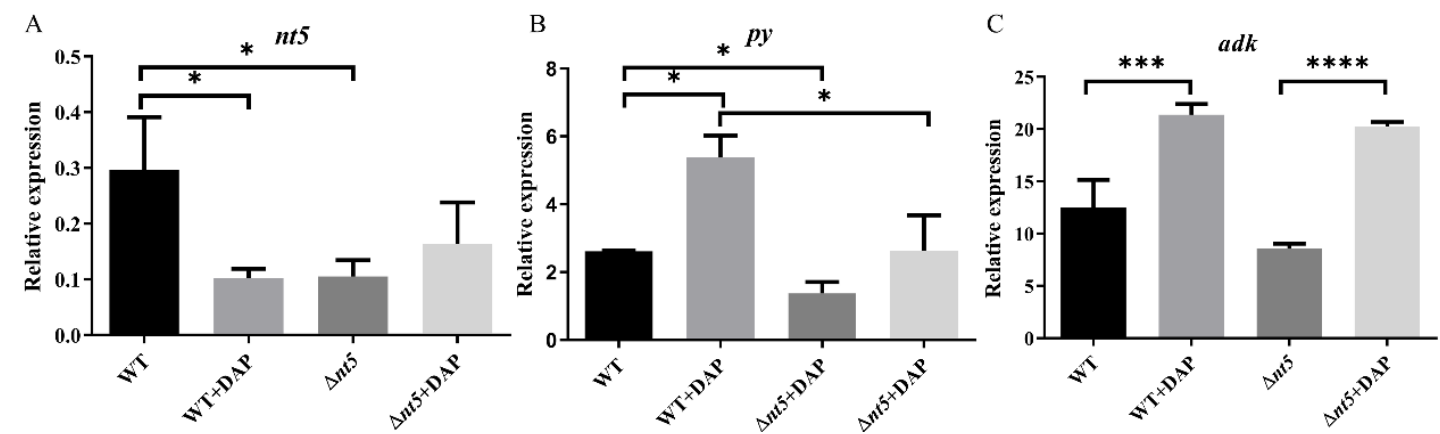

Fig. 3. The $n t 5$-mediated $p y$ and $a d k$ levels in response to DAP exposure in $S$. 
bioRxiv preprint doi: https://doi.org/10.1101/2022.02.09.479838; this version posted February 10, 2022. The copyright holder for this preprint (which was not certified by peer review) is the author/funder. All rights reserved. No reuse allowed without permission.

370 WT and $\Delta n t 5$. (C) The mRNA level of $a d k$ was upregulated in WT and $\Delta n t 5$ upon

$0.25 \mathrm{mg} / \mathrm{L}$ DAP treatment. DAP: daptomycin, $* \mathrm{P}<0.5$, *** $\mathrm{p}<0.001, * * * * \mathrm{P}<0.0001$.

\section{$n t 5$ deficiency impedes $S$. aureus-infected abscess formation}

$$
10^{6} \text { colony-forming units (CFU) of } S \text {. aureus WT, } \Delta n t 5 \text { was respectively }
$$

inoculated into $\mathrm{BALB} / \mathrm{c}$ mice by intravenous injection to investigate the role of gene

$n t 5$ for abscess formation. Ten mice were included for each group of $S$. aureus

inoculation, but two mice died of $S$. aureus WT infection before infection

kidneys were collected for observation of abscess profiles by $H \& E$ staining and colony counting respectively.

It was noticed that WT formed more abscesses in mouse kidneys compared with

H\&E staining analysis. There were several obvious lesions surrounded by infiltrating neutrophils in the kidney of mice inoculated with S. aureus WT. aureus $\Delta n t 5$ in mouse kidney was about a 40-times amount reduction compared with that of $S$. aureus WT infection $(\mathrm{P}<0.05)$, which indicates $n t 5$ gene silence greatly impedes infection ability of $S$. aureus.

391 Similarly, the colony formation quantity of $S$. aureus $\Delta n t 5$ surviving in mouse 
bioRxiv preprint doi: https://doi.org/10.1101/2022.02.09.479838; this version posted February 10, 2022. The copyright holder for this preprint (which was not certified by peer review) is the author/funder. All rights reserved. No reuse allowed without permission.

392 liver showed a 300-times reduction as compared with WT $(\mathrm{P}<0.05)$ (Fig. 4C), which 393 demonstrated infection ability of $\Delta n t 5$ to mouse liver was also obviously attenuated.

$n t 5$ silence recovers $S$. aureus-infected mouse body weight

396 The S. aureus $\Delta n t 5$ and WT strains were assessed to have influence on the body 397 weight of the infected mice. The mouse weight with $\Delta n t 5$ injection was about $20 \mathrm{~g}$, 398 which showed no significant change in body weight compared with the normal 399 BALB/c mice injected with PBS. But the weight of mouse infected with $S$. aureus 400 WT was greatly reduced to a mean value of $13 \mathrm{~g}$, which indicated $S$. aureus 401 WT-induced infection led to an obvious decrease of mouse body weight. Compared 402 with $S$. aureus WT, the mouse weight with $\Delta n t 5$ injection was recovered and 403 increased up to the normal mouse weight $(\mathrm{p}<0.001)$ (Fig. 4D). The $n t 5$ gene 404 expression attenuates $S$. aureus-infected mouse body weight.

405 In addition, the weight of each kidney from $S$. aureus $\Delta n t 5$-infected mouse was 406 about $0.18 \mathrm{~g}$, while a kidney ex vivo was reduced to $0.14 \mathrm{~g}$ in $S$. aureus WT-infected 407 mouse $(\mathrm{P}<0.0001)$ (Fig. 4E). It was consistent with changes of $S$. aureus-infected 408 mouse body weight. In general, $n t 5$ gene contributes to the infection capacity of $S$. 409 aureus, and $n t 5$ silence recovers $S$. aureus -infected mouse body weight as similar to 410 the normal mouse without infection. 
bioRxiv preprint doi: https://doi.org/10.1101/2022.02.09.479838; this version posted February 10, 2022. The copyright holder for this preprint (which was not certified by peer review) is the author/funder. All rights reserved. No reuse allowed without permission.
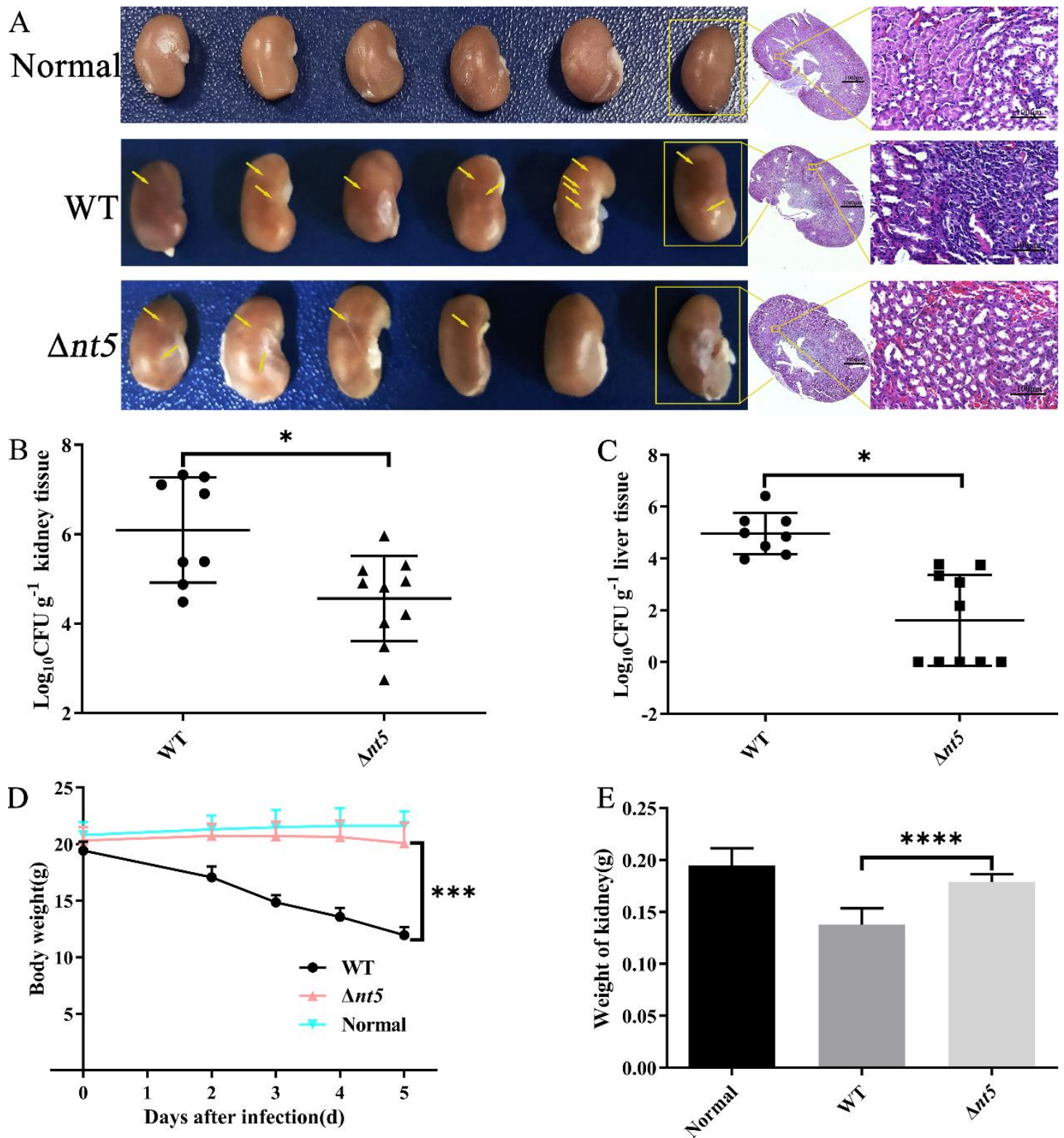

Fig. 4. Numbers of kidney abscess and liver bacterial loading were less in $S$.

414 kidney abscess. Yellow arrows indicated abscess lesions. (B-C) Staphylococcal

415 loading in mouse kidneys (B) and livers (C) after intravenous injection of $10^{6} \mathrm{CFU}$

416 of $S$. aureus WT and $\Delta n t 5$ for $5 \mathrm{~d}$. Ten mice were included in each group, but only 8

417 mice were finally enumerated in the $S$. aureus WT-infected group $(\mathrm{n}=8)$ due to 2

418 mice died before experiment ending. (D) Body weight of the mice inoculated with 
bioRxiv preprint doi: https://doi.org/10.1101/2022.02.09.479838; this version posted February 10, 2022. The copyright holder for this preprint (which was not certified by peer review) is the author/funder. All rights reserved. No reuse allowed without permission.

$419 \Delta n t 5$ was increased compared with WT. Normal group: normal BALB/c mice

420 injected with PBS. (E) Mass weight of mouse kidneys infected with S. aureus $\Delta n t 5$

421 was nearly recovered to that of normal mouse. $* \mathrm{P}<0.5, * * * \mathrm{p}<0.01, * * * * \mathrm{P}<0.0001$.

422

423

424

425

427

428

429

430

431

432

433

434

435

436 influenced biological activity of immune cells, and EDTA affected release of

437 complement C5a, thus affecting the phagocytosis effect of macrophages $(21,22)$.

438 Under same conditions at incubation with each donor's blood for $30 \mathrm{~min}$, the

439 remaining bacterial load of $\Delta n t 5$ was decreased than the WT $(\mathrm{p}<0.01)$ (Fig. 5D),

440 which indicated $n t 5$ gene silence improves phagocytosis of macrophages to $S$. aureus. 
bioRxiv preprint doi: https://doi.org/10.1101/2022.02.09.479838; this version posted February 10, 2022. The copyright holder for this preprint (which was not certified by peer review) is the author/funder. All rights reserved. No reuse allowed without permission.

441 But at incubation for $90 \mathrm{~min}$, the surviving bacterial quantity of the mutant $\Delta n t 5$ was

442 less than the $S$. aureus WT in both of two groups ( $<<0.05, \mathrm{p}<0.01)$ (Fig. 5C and 5D),

443 which indicated $S$. aureus $\Delta n t 5$ displayed a defect in staphylococcal escape from

444 phagocytic killing compared with the S. aureus WT.

445 Human innate immune system firstly responds to S. aureus infection, so we 446 further isolated $\mathrm{CD} 14^{+}$monocytes from human peripheral blood mononuclear cells

447 (PBMC) to detect the immune response to $S$. aureus $\Delta n t 5$ exposure. We sorted out

$448 \mathrm{CD}_{14}{ }^{+}$cells from 3 volunteers' blood samples and co-cultured CD14 ${ }^{+}$cells with $S$.

449 aureus WT and $\Delta n t 5$ respectively. The survival of bacteria was detected by recording

450 bacterial load at timed intervals via the formation of colonies on TSA (Fig. 5E). $S$.

451 aureus $\Delta n t 5$ was more easily cleared out by human $\mathrm{CD} 14^{+}$cells, which indicates that

$452 n t 5$ gene plays an important role in immune escape for $S$. aureus infection. Because

$453 \mathrm{CD}_{14}{ }^{+}$monocyte cells bind to cell wall peptidoglycan of $S$. aureus and then activate

454 phagocytosis to protect human body suffering from S. aureus infection (23).

455

$n+5$ gene is required for bacterial survival in mouse blood

457 In order to further verify the role of $n t 5$ gene in host immune response, we

458 directly injected $10^{6} \mathrm{CFUS}$. aureus WT and $\Delta n t 5$ into BALB/c mice to detect the

459 killing effect of host immune system on bacteria. In short time of bacterial infection

460 for 30 and $90 \mathrm{~min}$ in vivo, the quantity of surviving S. aureus WT was higher than

461 the mutant $\Delta n t 5$, which shows the mutant $\Delta n t 5$ is more easily cleared by mouse 462 immune system $(\mathrm{p}<0.01)$ (Fig. 5F). 
bioRxiv preprint doi: https://doi.org/10.1101/2022.02.09.479838; this version posted February 10, 2022. The copyright holder for this preprint (which was not certified by peer review) is the author/funder. All rights reserved. No reuse allowed without permission.

463 In conclusion, we have revealed that $n t 5$ is required for staphylococcal survival in

464 host as an extracellular pathogen, and $S$. aureus $n t 5$ gene plays a critical role for

465 staphylococcal escape from the phagocytic killing of host immune defense system to

466 promote their survival in host blood and tissues.
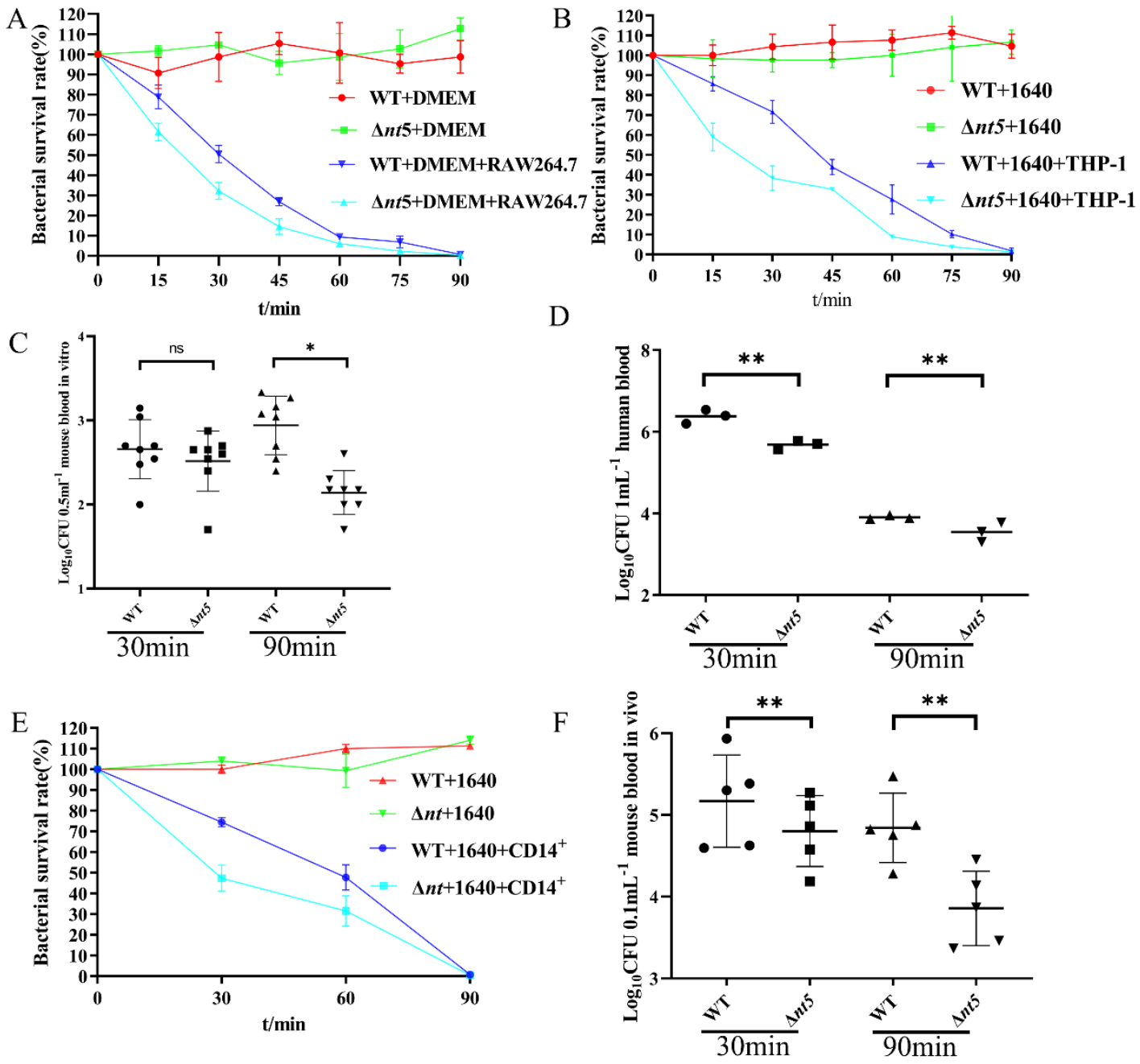

467

468 Fig. 5. Phagocytosis of $S$. aureus by host immune cells. (A-B) Phagocytosis of $S$.

469 aureus by rat macrophage cell line RAW264.7 (A) and human monocyte cell line

470 THP-1 (B). The survival rate of bacteria was calculated by recording the surviving

471 CFU of $S$. aureus on TSA. (C-D) The surviving ability of $S$. aureus $\Delta n t 5$ in

472 peripheral blood in vitro. $S$. aureus WT, $\Delta n t 5$ was co-cultured in vitro with blood

473 sample collected from 8 BALB/c mice (C) and 3 human volunteers (D) by recording 
474 bacterial load at timed intervals. (E-F) Phagocytosis of $S$. aureus $\Delta n t 5$ by human (E)

475 and mouse (F) $\mathrm{CD}_{14}{ }^{+}$immune cells in vitro. The survival rate of bacteria was

476 calculated by recording the surviving CFU of $S$. aureus on TSA.

\section{$n t 5$ silence has no influence on hemolysis}

We detected whether the silence of $n t 5$ gene affected the hemolytic activity of

480 bacteria. We inoculated $10^{5} \mathrm{CFU}$ bacteria on blood agar plate and cultured at $37^{\circ} \mathrm{C}$

481 for $16 \mathrm{~h}$. The silence of $n t 5$ gene had no influence on the hemolytic activity of 482 bacteria (Fig. 6A and 6B). Therefore, the attenuation of bacterial virulence caused by 483 the silence of $n t 5$ gene is mainly reflected in the formation of abscess.

484 In addition, we verified gene stability of $n t 5$ silence mutant grown on the TSA 485 plate that was derived from the liver and kidney tissue homogenate extracted from $S$. 486 aureus $\Delta n t 5$-infected mouse. The DNA sequencing showed the growing bacteria 487 were consistent with $S$. aureus $\Delta n t 5$ (Fig 6C), which indicates the $n t 5^{\text {C166T }}$ mutation 488 via pnCasSA-BEC single base editing system is genetically stable. 

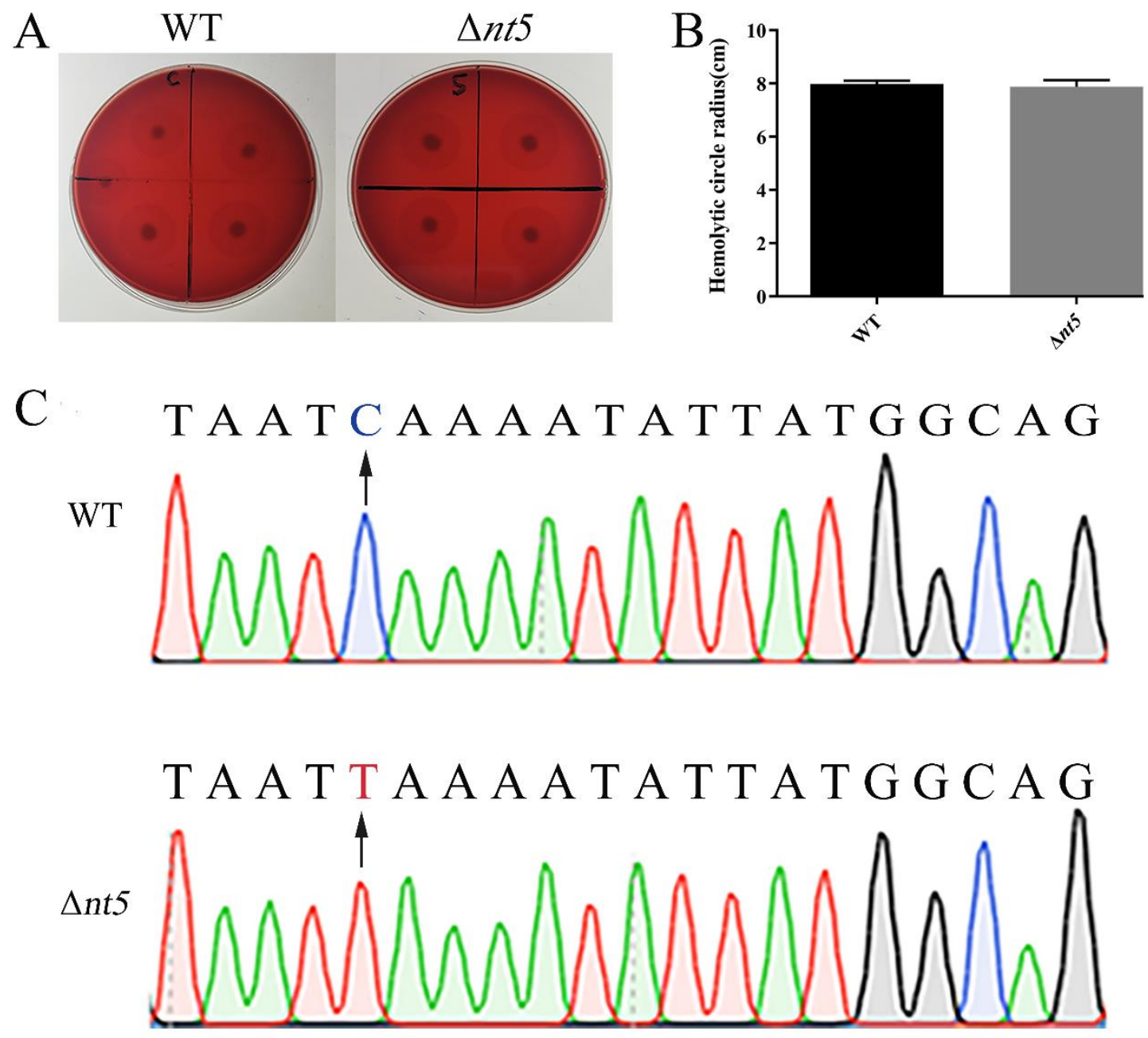

490 Fig. 6. Hemolytic activity of $S$. aureus $\mathbf{\Delta n t 5}$. (A-B) Size of hemolytic ring formed

491 by WT and $\Delta n t 5$ on blood agar plate. (C) The $n t 5$ gene sequencing of $S$. aureus $\Delta n t 5$

492 colony from mouse liver homogenate and kidney homogenate.

\section{Discussion}

495 Almost all archaea and many bacteria achieve adaptive immunity through a 496 diverse set of CRISPR-Cas systems, which has proven to be extraordinarily simple 497 and efficient in DNA and RNA editing, nucleic acid detection, and disease diagnosis

498 (24,25). The CRISPR/Cas9 system has been engineered for gene editing in various 499 organisms which is originally confirmed as a bacterial immune syste (18). The 
bioRxiv preprint doi: https://doi.org/10.1101/2022.02.09.479838; this version posted February 10, 2022. The copyright holder for this preprint (which was not certified by peer review) is the author/funder. All rights reserved. No reuse allowed without permission.

500 pCasSA system is one kind of specific CRISPR/Cas9 designed for S. aureus gene

501 knockdown (18). But most of $S$. aureus, especially clinical isolates, cannot survive

502 due to the double-stranded DNA breaks induced by the pCasSA system and the lack

503 of the homologous recombination repair process. A novel base editing system based

504 on CRISPR RNA-guided cytidine deaminase (17) is available to construct S. aureus

$505 \Delta n t 5$ since this genome editing approach does not require formation of

506 double-stranded DNA breaks or provision of a donor DNA template, which allows

507 for rapid and efficient genetic manipulation and drug-target exploration in S. aureus 508 (24).

509 Base editing method is an efficient gene silence strategy, which induces 510 single-nucleotide changes in the DNA of living cells. There are two kinds of base 511 editors including the cytidine editor and the adenosine editor. Efficient editing by the $512 \mathrm{C} / \mathrm{T}$ conversion "base editor" requires the presence of a PAM motif with NGG 513 nucleotide sequence, which has an editable window from positions 4 to 8 in the 514 spacer sequence (18). This PAM requirement limits the number of sites in the 515 bacterial genome. An editable site of the pnCasSA-BEC system is essential for 516 highly efficient base editing. In addition, it has a disadvantage that mutation site 517 could not be verified by mRNA levels compared with CRISPR/Cas9 system. For 518 example, the mRNA expression level of $n t 5$ gene in our study is still observed in $519 \Delta n t 5$, so DNA sequencing is required to confirm gene mutations into terminate 520 codons (26).

521 Herein, we focus on physiological changes in $S$. aureus with $n t 5$ gene silence. The 
bioRxiv preprint doi: https://doi.org/10.1101/2022.02.09.479838; this version posted February 10, 2022. The copyright holder for this preprint (which was not certified by peer review) is the author/funder. All rights reserved. No reuse allowed without permission.

522 silence of $n t 5$ gene influences the expression of py and adk genes, but it does not

523 affect the growth of bacteria, which indicates metabolic compensation of nucleic

524 acid pathway in bacteria (27). And we have revealed that $n t 5$-mediated nucleic acid

525 pathway in S. aureus is obviously disturbed due to increase of its pathogenic genes

526 py ladk and $n t 5$ decrease in response to antibiotics treatment. These observations are

527 in line with the bacterial proteome profiling of $S$. aureus ATCC 25923 upon DAP

528 treatment (7). Meanwhile, it also shows that DAP not only disrupts bacterial cell

529 membrane, but also affects the $n t 5$-mediated nucleic acid pathway in $S$. aureus,

530 which contributes to the effective antibacterial activity of DAP (28). Therefore,

531 disruption of $n t 5$-mediated signaling paves possible therapeutic opportunities for

532 treatment of infections and provides a direction for finding new target of DAP.

533 S. aureus usually causes serious infections, with an annual incidence of 20 to 50

534 cases per 100,000 people. Approximately $10 \%$ to $30 \%$ of these patients die from $S$.

535 aureus infection, which accounts for a greater number of deaths than for AIDS,

536 tuberculosis, and viral hepatitis combine (29). Although antibiotics, such as

537 vancomycin and DAP, have powerful antibacterial activity on $S$. aureus, the increase

538 of bacterial drug resistance leads to the gradual failure of antibiotics. It is necessary

539 to explore the pathogenic mechanism of S. aureus.

540 By now, this is the first study to reveal role of $n t 5$ gene in abscess formation and

541 immune evasion. The in vivo analysis in mouse sepsis model indicates that $S$. aureus

$542 n t 5$ gene is required for kidney abscess formation and is helpful for bacterial evasion

543 from the host immune response during infection. Immune evasion is an important 
bioRxiv preprint doi: https://doi.org/10.1101/2022.02.09.479838; this version posted February 10, 2022. The copyright holder for this preprint (which was not certified by peer review) is the author/funder. All rights reserved. No reuse allowed without permission.

544 process in which microorganisms directly modulate host-immune system in response

545 to pathogens (30). Of note, in some bacteria, NT5 contributes to immune evasion by

546 dephosphorylating adenosine mono-, di-, or tri-phosphates, thereby increasing the

547 concentration of adenosine.

548 In S. aureus, NT5 activity is the mediator of the virulence attributes of adsA (16).

549 And NT5 has classic lipoprotein signal sequence which belongs to the haloacid

550 dehalogenase superfamily and is similar to haemophilus influenzae lipoprotein E. A

551 critical role of NT5 in haemophilus influenzae is the degradation of external riboside

552 (30). S. aureus adsA is an adenosine synthase to own NT5 activity. AdsA converts

553 neutrophil extracellular traps to dAdo during infection, and dAdo production

554 represents a general immune evasion mechanism for microbial pathogens (31).

555 Pathogenic bacteria use synthesized dAdo to evade host defenses (14). The

556 production of dAdo by S. aureus adsA induces caspase-3-mediated death of human

557 macrophages (14). Streptococcus suis produces dAdo by NT5 causing

558 monocytopenia in mouse blood in vivo, which suggests the immunosuppressive

559 activity of Ado on immune responses in vivo (8). Perturbation of adenosine levels is

560 likely to affect host immune responses during infection $(31,32)$.

561 Moreover, the global proteome and phosphor-proteome of sepsis kidney injury

562 also reveal that caspase-1 is significantly up-regulated in the cecal ligation and

563 puncture-induced sepsis, which mediates gasdermin D cleavage and activation (33).

564 Gasdermin D dependent pyroptosis cell death has been revealed for the first time in

565 nonseptic acute kidney injury (34). In the kidney abscess caused by $S$. aureus, it's 
bioRxiv preprint doi: https://doi.org/10.1101/2022.02.09.479838; this version posted February 10, 2022. The copyright holder for this preprint (which was not certified by peer review) is the author/funder. All rights reserved. No reuse allowed without permission.

566 valuable to further investigate whether does exist a similar mechanism with cecal

567 ligation and puncture-induced sepsis.

568 Ex vivo infection of whole blood is a valuable tool to study $S$. aureus virulence

569 factors and the host innate immune responses. In order to consider effects of cellular

570 mediators, the coagulation cascade must be inhibited to avoid clotting. However,

571 EDTA, a strong chelator of $\mathrm{Ca}^{2+}$ as well as $\mathrm{Mg}^{2+}$, blocks coagulation as well as

572 complement entirely (21). Blocking of C5a or C5aR1 attenuates phagocytosis and

573 increases the extracellular growth of $S$. aureus in blood (22). Besides the host

574 response, the anticoagulants might directly affect the bacteria growth. EDTA as a

575 chelator of $\mathrm{Ca}^{2+}$ is present on the blood tube, which has a strong inhibitory effect on

576 S. aureus growth when $S$. aureus is phagocytosed by macrophages in vitro. Hence,

577 the citrate or heparin as anticoagulant should be selected to collect host blood sample,

578 which has little effect on host immune response and bacterial growth (21).

$579 S$. aureus secretes a number of host-injurious toxins, among the most prominent of

580 which is the small $\beta$-barrel pore-forming toxin $\alpha$-hemolysin. Initially named based

581 on its properties as a red blood cell lytic toxin, early studies suggested a far greater

582 complexity of $\alpha$-hemolysin action as nucleated cells also exhibited distinct responses

583 to intoxication (35). However, our experimental results show that gene $n t 5$ does not

584 affect the hemolytic activity of $S$. aureus. We speculate that the virulence of gene $n t 5$

585 is mainly manifested in sepsis and immune escape.

586 In conclusion, we have provided direct evidences of the role of $n t 5$ gene toward

587 staphylococcal infection ability. We have revealed $n t 5$ gene of $S$. aureus is required 
bioRxiv preprint doi: https://doi.org/10.1101/2022.02.09.479838; this version posted February 10, 2022. The copyright holder for this preprint (which was not certified by peer review) is the author/funder. All rights reserved. No reuse allowed without permission.

588 for host infection and abscess formation. These results are helpful for the 589 development of NT5 inhibitors as a new strategy for rendering $S$. aureus susceptible 590 to human host defence.

591

592 Acknowledgments

593 This work was supported by the Projects of International Cooperation and 594 Exchanges from Sichuan Province (2020YFH0094), Chengdu Science and 595 Technology Bureau (2020-GH02-00056-HZ).

596

\section{Reference}

598 1. Turner NA, Sharma-Kuinkel BK, Maskarinec SA, Eichenberger EM, Shah PP 599 Carugati M, Holland TL, Fowler VG Jr. 2019. Methicillin-resistant 600 Staphylococcus aureus: an overview of basic and clinical research. Nat Rev $601 \quad$ Microbiol. 17: 203-218.

602

2. Windels EM, Van den Bergh B, Michiels J. 2020. Bacteria under antibiotic 603 attack: Different strategies for evolutionary adaptation. PLoS Pathog. 16:

604 e1008431.

605

3. Ye Y, Xia Z, Zhang D, Sheng Z, Zhang P, Zhu H, Xu N, Liang S. 2019. 606 Multifunctional pharmaceutical effects of the antibiotic daptomycin. Biomed 607 Res Int. 2019: 8609218.

4. Durand GA, Raoult D, Dubourg G. 2019. Antibiotic discovery: history, methods 
bioRxiv preprint doi: https://doi.org/10.1101/2022.02.09.479838; this version posted February 10, 2022. The copyright holder for this preprint (which was not certified by peer review) is the author/funder. All rights reserved. No reuse allowed without permission.

609 and perspectives. Int J Antimicrob Agents. 53: 371-382.

610 5. Heidary M, Khosravi AD, Khoshnood S, Nasiri MJ, Soleimani S, Goudarzi M. 2018. Daptomycin. J Antimicrob Chemother. 73: 1-11.

6. Ma W, Zhang D, Li G, Liu J, He g, Zhang P, Yang L, Zhu H, Xu N, Liang S. 2017. Antibacterial mechanism of daptomycin antibiotic against Staphylococcus aureus based on a quantitative bacterial proteome analysis. J proteomics. 150: $242-251$

7. Soh KY, M S Loh j, Proft T. 2020. Cell wall-anchored 5'-nucleotidases in gram-positive cocci. Mol Microbiol. 113: 691-698.

8. Dai J, Lai L, Tang H, Wang W, Wang S, Lu C, Yao H, Fan H, Wu Z. 2018. Streptococcus suis synthesizes deoxyadenosine and adenosine by 5'-nucleotidase to dampen host immune responses. Virulence. 9: 1509-1520.

9. Tremblay LW, Dunaway-Mariano D, Allen KN. 2006. Structure and activity analyses of Escherichia coli K-12 NagD provide insight into the evolution of biochemical function in the haloalkanoic acid dehalogenase superfamily. Ishikawa S, Yoshida KI. 2016. Bacillus subtilis 5'-nucleotidases with various functions and substrate specificities. BMC Microbiol. 16: 249. 
bioRxiv preprint doi: https://doi.org/10.1101/2022.02.09.479838; this version posted February 10, 2022. The copyright holder for this preprint (which was not certified by peer review) is the author/funder. All rights reserved. No reuse allowed without permission.

629 infections and immune evasion strategies of Staphylococcus aureus. Curr Opin

$630 \quad$ Microbiol. 15: 92-99.

631 12. Alam MS, Costales MG, Cavanaugh C, Williams K. 2015. Extracellular 632 adenosine generation in the regulation of pro-inflammatory responses and 633 pathogen colonization. Biomolecules. 5: 775-792.

634 13. Lee JS, Yilmaz O. 2018. Unfolding role of a danger molecule adenosine 635 signaling in modulation of microbial infection and host cell response. Int J Mol $636 \quad$ Sci. 19:199.

637 14. Winstel V, Missiakas D, Schneewind O. 2018. Staphylococcus aureus targets the 638 purine salvage pathway to kill phagocytes. Proc Natl Acad Sci U S A. 115: $639 \quad 6846-6851$.

640 15. Thammavongsa V, Kern JW, Missiakas DM, Schneewind O. 2009. 641 Staphylococcus aureus synthesizes adenosine to escape host immune responses. $642 \quad J$ Exp Med. 206: 2417-2427.

643 16. Thammavongsa V, Schneewind O, Missiakas DM. 2011. Enzymatic properties 644 of Staphylococcus aureus adenosine synthase (AdsA). BMC Biochem. 12: 56.

645 17. Gu T, Zhao S, Pi Y, Chen W, Chen C, Liu Q, Li M, Han D, Ji Q. 2018. Highly 646 efficient base editing in Staphylococcus aureus using an engineered CRISPR $647 \quad$ RNA-guided cytidine deaminase. Chem Sci. 9: 3248-3253.

648 18. Chen W, Zhang Y, Yeo WS, Bae T, Ji Q. 2017. Rapid and efficient genome 
bioRxiv preprint doi: https://doi.org/10.1101/2022.02.09.479838; this version posted February 10, 2022. The copyright holder for this preprint (which was not certified by peer review) is the author/funder. All rights reserved. No reuse allowed without permission.

649 editing in Staphylococcus aureus by using an engineered CRISPR/Cas9 system.

$650 \quad J$ Am Chem Soc. 139: 3790-3795.

651 19. Zhang D, Ma W, He Y, He G, Zhang P, Zhu H, Xu N, Liang S. 2016. Data of the 652 interacting protein networks and nucleotide metabolism pathways related to 653 NDK and NT5. Data in Brief. 9: 1063-1066.

654 20. Speert DP, Gordon S. 1992. Phagocytosis of unopsonized pseudomonas 655 aeruginosa by murine macrophages is a two-step process requiring glucose. $\mathrm{J}$ $656 \quad$ Clin Invest. 90: 85-92.

657 21. Strobel L, Johswih KO. 2018. Anticoagulants impact on innate immune 658 659 responses and bacterial survival in whole blood models of Neisseria meningitidisinfection. Comparative Study. 8: 10225.

660

22. Ehrnstrom B, Kojen JF, Giambelluca M, Ryan L, Moen SH, Hu Z, Yin H, 661 Mollnes TE, Damas JK, Espevik T, Stenvik J. 2020. TLR8 and complement C5 induce cytokine release and thrombin activation in human whole blood challenged with Gram-positive bacteria. J Leukoc Biol. 107: 673-683.

664

23. Wu ZH, Zhang ZX, Lei ZH, Lei P. 2019. CD14: Biology and role in the 665 pathogenesis of disease. Cytokine Growth Factor Rev. 48: 24-31.

24. Kim YB, Komor AC, Levy JM, Packer M, Zhao K, Liu D. 2017. Increasing the genome-targeting scope and precision of base editing with engineered Cas9-cytidine deaminase fusions. Nat Biotechnol. 35: 371-376. 
bioRxiv preprint doi: https://doi.org/10.1101/2022.02.09.479838; this version posted February 10, 2022. The copyright holder for this preprint (which was not certified by peer review) is the author/funder. All rights reserved. No reuse allowed without permission.

669 25. Lin P, Qin S, Pu Q, Wang Z, Wu Q, Gao P, Schettler J, Guo K, Li R, Li G,

670

671

672

673

674

675

676

677

678

679

680

681

682

683

684

685

686

687

688

Huang C, Wei Y, Gao GF, Jiang J, Wu M. 2020. CRISPR-Cas13 Inhibitors block

RNA editing in bacteria and mammalian cells. Mol Cell. 78: 850-861.

26. Wang X, Liu Z, Li G, Dang L, Huang S, He L, Ma Y, Li C, Liu M, Yang G, Huang X, Zhou F, Ma X. 2020. Efficient gene silencing by adenine base editor-mediated start codon mutation. Mol Ther. 28: 431-440.

27. Zeinert RD, Baniasadi H, Tu BP, Chien P. 2020. The Lon protease links nucleotide metabolism with proteotoxic stress. Mol Cell. 79: 758-767.

28. Zhang D, He Y, Ye Y, Ma Y, Zhang P, Zhu H, Xu N, Liang S. 2019. Little antimicrobial peptides with big therapeutic roles. Protein Pept Lett. 26: 564-578.

29. Hal SJ, Jensen SO, Vaska VL, Espedido BA, Paterson D, Gosbell LB. 2012. Predictors of mortality in Staphylococcus aureus bacteremia. Clin Microbiol Rev. 2: 362-386.

30. Gerlach D, Guo Y, De Castro C, Kim SH, Schlatterer K, Xu F, Pereira C, Seeberger PH, Ali S, Codée J, Sirisarn W, Schulte B, Wolz C, Larsen J, Molinaro A, Lee BL, Xia G, Stehle T, Peschel A. 2018. Methicillin-resistant Staphylococcus aureus alters cell wall glycosylation to evade immunity. Nature. 563: 705-709.

31. Thammavongsa V, Kim HK, Missiakas D, Schneewind O. 2015. Staphylococcal manipulation of host immune responses. Nat Rev Microbiol. 13: 529-543. 
689 32. Zhang BZ, Cai J, Yu B, Xiong L, Lin Q, Yang XY, Xu C, Zheng S, Kao RY, Sze

690 K, Yuen KY, Huang JD. 2017. Immunotherapy targeting adenosine synthase a 691 decreases severity of Staphylococcus aureus infection in mouse model. J Infect 692 Dis. 216: 245-253.

693 33. Lin YH, Platt MP, Fu H, Gui Y, Wang Y, Gonzalez-Juarbe N, Zhou D, Yu Y. 694 2020. Global proteome and phosphoproteome characterization of sepsis-induced 695 kidney injury. Mol Cell Proteomics. 19: 2030-2047.

696 34. Miao N, Yin F, Xie H, Wang Y, Xu Y, Shen Y, Xu D, Yin J, Wang B, Zhou Z, 697 Cheng Q, Chen P, Xue H, Zhou L, Liu J, Wang X, Zhang W, Lu L. 2019. The 698 cleavage of gasdermin D by caspase-11 promotes tubular epithelial cell 699 pyroptosis and urinary IL-18 excretion in acute kidney injury. Kidney Int. 96: $1105-1120$. of intrigue. Toxins. 5: 1140-1166. 


\section{S1 Table. Primers used in this study}

\begin{tabular}{|c|c|}
\hline Primer & Sequence (5'-3') \\
\hline$n t 5$ spacer For (Forward primer) & GAAATAATCAAAATATTATGGCAG \\
\hline$n t 5$ spacer Rev (Reverse primer) & AAACCTGCCATAATATTTTGATTA \\
\hline$n t 5$ check spacer For & CATCATTATCGGTAGCGGT \\
\hline$n t 5$ check spacer Rev & GTAGACGTCCAATTCATATA \\
\hline PnCasSA-BEC check for & AGCCTATGGAAAAACGCCAG \\
\hline pnCasSA-BEC check rev & GTAAAACACTTACTAATTCTC \\
\hline$n t 5$ For & ACAGTGCAAAGACTCAGTTAGA \\
\hline$n t 5 \mathrm{Rev}$ & TGCATAGCCTTGATATGGAGAA \\
\hline py For & GCTGTATGTGCAACCGAAATAC \\
\hline py Rev & TGAAGCAGCCCAAGATTACA \\
\hline$a d k$ For & TGTTCTTGGGAAGCCATCTAAT \\
\hline$a d k \operatorname{Rev}$ & GTTCCTGATGAAGTGACTGTAGG \\
\hline tpi For & AGCTAACGATGTTGTAGGTGAG \\
\hline tpi Rev & GATTGCCCAGATTGGTTCATAAG \\
\hline
\end{tabular}

